\title{
LEADERSHIP STYLE, SELF-SACRIFICE, AND TEAM IDENTIFICATION
}

\author{
Stefano RuggieRI \\ University of Palermo and Euro-Mediterranean Institute of Science \\ and Technology, Palermo, Italy \\ Costanza Scaffidi AbBate \\ University of Palermo
}

\begin{abstract}
Leadership is a group feature that directly impacts on team identification. Effective leaders are especially capable of fostering group cohesiveness and promoting efficacy in goal attainment. We assessed the relationship between transactional and transformational leadership style, team identification, and leader self-sacrifice. Participants were 186 call center employees who were headed by a leader who operated with either a transactional or a transformational leadership style. The employees reported their level of team identification and leader self-sacrifice. Results show how, in either the transactional or transformational leadership condition, levels of leadership and self-sacrifice were related to team identification, as well as the interaction effect between transactional leadership level and leader self-sacrifice. Our findings demonstrate how different leadership styles play a diverse role in this relationship.
\end{abstract}

Keywords: transactional leadership, transformational leadership, self-sacrifice, team identification, leadership style.

Team identification is one of the most important factors in defining one's identity. Past researchers have shown that employee identification is a fundamental predictor of efforts on behalf of the organization (Riketta, 2005). Hence, there is an increasing interest in current research, in employee organizational identification and the factors that promote it in teamwork. Team identification

Stefano Ruggieri, Department of Psychology, University of Palermo and Euro-Mediterranean Institute of Science and Technology, Italy; Costanza Scaffidi Abbate, Department of Psychology, University of Palermo.

Correspondence concerning this article should be addressed to: Stefano Ruggieri, Department of Psychology, University of Palermo, Viale delle Scienze, Edificio 15, I-90128 Palermo, Italy. Email: stefanoruggieri@gmail.com 
is defined as "the extent to which an individual team member identifies with a specific organizational team rather than social groups in general" (Gundlach, Zivnuska, \& Stoner, 2006, p. 1608). It represents individual members' perceived sense of belonging to a particular team. Team identification motivates members to behave in accordance with the group's interests and strengthens the ties between members.

Leadership influence is a promising research approach related to team identification. According to the self-concept-based theory of leadership (Shamir, House, \& Arthur, 1993) effective leaders are very adept at fostering employee group identification. Following this theory, van Dick, Hirst, Grojean, and Wieseke (2007) developed a transfer model of organizational identification (OI) that links leader OI to follower OI.

An approach to the study of leadership in which the complexity of the changes in modern organizational contexts are described, uses the transformational/ transactional framework (Bass, 1985; Bass \& Avolio, 1995). Bass discusses the difference between a transactional leadership model, in which the leader emerges as a result of transactions and exchanges with group members, and a transformational leadership model, in which the leader adapts to the changes and instability of the situation and involves, motivates, and supports followers in a manner consistent with the required transformations.

In the transactional leadership model, leaders are negotiating agents who conciliate and sometimes compromise to obtain greater decision-making power within the group. To achieve this goal, they perform a series of actions that enable them to influence and convince the followers, who are capable of providing valuable support. The activity of leaders consists of implementing interpersonal transactions in which tasks, expectations, and related awards are indicated and clarified. The aim of rewards and punishments is not to transform the followers but to ensure that the expected results are achieved.

Transformational leadership is the other side of the coin. The operational mode of a leader whose leadership style is transformational, causes followers to seek rewards within themselves and facilitates their personal growth and self-awareness (Scaffidi Abbate \& Ruggieri, 2008). Unlike the transactional leader who makes use of existing interests, the transformational leader changes each individual's value system to construct a new one constituted by common goals, and actively engages with followers by obtaining their collaboration, and encouraging them to identify with an organizational vision beyond their own self-interest. Followers are encouraged to enhance their group and organizational selves by concentrating on long-term goals and attempting to change situations. This is accomplished by leaders who support their followers by acting as guides and motivators in the change and growth process. The effects, in terms of the 
effectiveness of use of either a transactional or a transformational leadership style, are found both in face-to-face and computer-mediated communication interactions (Purvanova \& Bono, 2009; Ruggieri, 2009).

A topic that has recently attracted increasing attention from leadership researchers is the self-sacrifice of leaders, but to date, relatively little is known about the mediators of the effects of leadership level and self-sacrifice on group factors, especially the effects on group behavior (De Cremer \& van Knippenberg, 2004). Leaders who display self-sacrificial behavior are considered by their followers to be more effective, charismatic, and legitimate than are self-benefiting leaders (Hoogervorst, De Cremer, van Dijke, \& Mayer, 2012). Self-sacrifice involves the leader being willing to incur personal costs or run the risk of such costs to serve the goals and mission of the group or organization (Conger \& Kanungo, 1987). Perceptions of effectiveness are positively affected when a leader is regarded by followers as being self-sacrificing. For example, Choi and Mai-Dalton (1999) showed that followers were most ready to reciprocate the behavior of a self-sacrificial leader. Self-sacrificial leadership goes beyond an individual's motivation to help others and can be defined as "the total/partial abandonment, and/or permanent/temporary postponement of personal interests, privileges, or welfare in the (a) division of labor, (b) distribution of rewards, and/or (c) exercise of power" (Choi \& Mai-Dalton, 1998, p. 479). Leaders also demonstrate self-sacrifice by giving up their rewards or refraining from using power for personal benefit (Choi \& Mai-Dalton, 1998; Scaffidi Abbate \& Ruggieri, 2011).

\section{Hypotheses}

Although previous researchers have investigated the relationships among leadership, team identification, and leaders' self-sacrifice, they have not investigated in depth the relationship involving different leadership styles. It is known that different leadership styles evoke different levels of team cohesiveness, job satisfaction, and self-esteem. For example, within the transactional/transformational leadership framework, Bass (1985) and Bass \& Avolio (1995) have shown that, when the leader uses a transactional style, followers are motivated to obtain personal rewards that only the leader can grant, and to replicate behaviors that have been successful, discarding unsuccessful ones. When the leadership style is transformational, the fostering of the group process goes beyond the exchange of incentives and corrective transactions between leaders and followers. Therefore, the following hypotheses were proposed:

Hypothesis 1: There will be a stronger relationship between transformational leadership and team identification than between transactional leadership and team identification. 
Hypothesis 2: There will be a relationship between transformational leadership and leader self-sacrifice, but there will be no relationship between transactional leadership and leader self-sacrifice.

\section{Method}

\section{Participants and Procedure}

Participants were 186 call center employees ( 83 men and 103 women) aged between 23 and 42 years $(M=31.3, S D=5.67)$, of whom $62 \%$ worked part time. They were all voluntarily enrolled from a group of about 300 workers. Participants were asked to think about their leader and report on their leadership style by responding to a survey, which we distributed to the participants and which was collected 10 days later by a research assistant.

\section{Instruments}

Participants indicated their level of agreement with each statement.

Team identification. Participants responded to six items in a survey derived from Mael and Ashforth (1992) and van Knippenberg and van Schie (2000), on a 6-point scale $(\alpha=.71)$ ranging from 1 (strongly disagree) to 6 (strongly agree). They were told to think about their work team. A sample item is: "When I speak of my work group, I usually say us rather than them".

Self-sacrifice. Self-sacrificial leadership was assessed with five items inspired by the work of Conger and Kanungo (1998), on a 5-point Likert-type scale ( $\alpha$ $=.82$ ) ranging from 1 (strongly disagree) to 5 (strongly agree). A sample item is: "My supervisor is willing to make personal sacrifices in the team's interest".

Transactional and transformational leadership. Employees' perception level of transactional and transformational leadership was assessed using Bass and Avolio's (1995) Multifactor Leadership Questionnaire $(\alpha=.78) 5 X$-Short form (MLQ 5X-Short). This questionnaire has 45 items that are assessed on a 5-point scale ranging from 0 (not at all) to 4 (frequently, if not always).

\section{Results}

We then divided the participants into two groups: employees headed by transactional leaders (97 participants) and employees headed by transformational leaders (89 participants). The main and interaction effects of the level of leadership (transactional and transformational) and leader self-sacrifice on team identification were calculated separately for each group, using a hierarchical regression model. We centered transactional and transformational leadership and leader self-sacrifice prior to the analyses and based the interaction term on these centered scores. The means, standard deviations, and intercorrelations for the two groups are reported in Table 1, and the regression results are shown in Table 2. 
Table 1. Means, Standard Deviations, and Intercorrelations of Team Identification, Selfsacrifice, and Leadership in Transactional and Transformational Leadership Conditions

\begin{tabular}{lccccc}
\hline Transactional leadership condition & $M$ & $S D$ & 1 & 2 & 3 \\
\hline Team identification & 4.20 & 1.39 & - & - & - \\
Self-sacrifice & 3.54 & 1.06 & $.29^{* *}$ & - & - \\
Transactional leadership & 3.41 & 1.18 & $.39^{* *}$ & $-.25^{*}$ & - \\
Transformational leadership condition & $M$ & $S D$ & 1 & 2 & 3 \\
Team identification & 4.43 & 1.60 & - & - & - \\
Self-sacrifice & 3.48 & 1.24 & $.57^{* *}$ & - & - \\
Transformational leadership & 3.47 & 1.37 & $.63^{* *}$ & $.32^{* *}$ & - \\
\hline
\end{tabular}

Note. $n_{\text {transactional }}=97 ; n_{\text {transformational }}=89$.

${ }^{*} p<.05,{ }^{* *} p<.01$.

Table 2. Hierarchical Regression Analysis (Centered) of Team Identification on Leader Selfsacrifice and Leader Style

\begin{tabular}{lccccc}
\hline & $\beta$ & $R^{2}$ & Adj. $R^{2}$ & $R^{2}$ change & $d f$ \\
\hline Step 1 & $.41^{* *}$ & .31 & .30 & .15 & 94 \\
Self-sacrifice & $.50^{* *}$ & & & & \\
Transactional leadership & & .33 & .31 & .02 & 93 \\
Step 2 & $.41^{* *}$ & & & & \\
Self-sacrifice & $.49^{* *}$ & & & \\
Transactional leadership & .12 & & & \\
Self-sacrifice $\times$ Transactional leadership & & & & & \\
& & .53 & .52 & .13 & \\
Step 1 & $.39^{* *}$ & & & & \\
Self-sacrifice & $.49^{* *}$ & & & & \\
Transformational leadership & $.37^{* *}$ & .57 & .55 & & \\
Step 2 & $.39^{* *}$ & & & & \\
Self-sacrifice & $-.20^{*}$ & & & & \\
Transformational leadership & & & & & \\
Self-sacrifice $\times$ Transformational leadership & & & \\
\hline
\end{tabular}

Note. ${ }^{* *} p<.001,{ }^{*} p<.01$.

Leadership style and self-sacrifice were positively related to team identification in both transactional and transformational conditions, but a stronger relationship was observed in the transformational context.

A further difference is related to the interaction effects of the level of leadership and self-sacrifice. Simple slopes analysis (Aiken \& West, 1991) revealed the absence of interaction effect in the transformational leadership condition and the presence of interaction effect in the transactional leadership condition. Specifically, it was revealed that transactional leadership levels were more positively related to team identification when leader self-sacrifice was low (1SD below the mean; $\beta=.43, p<.001)$ than when leader self-sacrifice was high (1 $S D$ above the mean; $\beta=.26, p<.001)$. 


\section{Discussion and Conclusion}

Previous researchers (e.g., Shamir et al., 1993) have suggested that, when a leader is self-sacrificing, followers link their sense of identity to the goals and mission of the organization. This is an important explanation for the ability of a self-sacrificial leader to motivate followers to go beyond their self-interest. By displaying self-sacrificial behavior on behalf of the group, the leader may, thus, identify the group as being of value and deserving of individuals' dedicated efforts (De Cremer \& van Knippenberg, 2004).

Our findings provide further evidence that team identification in an employee group is affected by the presence of high levels of transactional and transformational leadership. In particular, high levels of transformational leadership ensure higher levels of team identification than do high levels of transactional leadership. Furthermore, as Riketta (2005) has shown, the level of leader self-sacrifice is positively associated with team identification. Our results showed that, among our participant group, this relationship, although of a different strength, existed in both leadership conditions. This confirms the existence of a similar relationship pattern in both leadership style conditions. Thus, our first hypothesis was supported, but the second hypothesis was not supported. Transformational leaders, in fact, tend to increase their personal bond with the team. Conversely, transactional leaders show a lower level of interrelation with their followers' team identification. According to our results there were also low levels - but not an absence as we predicted in Hypothesis 2 - of interrelation in the relationship between self-sacrifice and team identification.

Results that we found new and interesting emerged when we analyzed the interaction effects. In the transformational leadership condition, there was no interaction effect between levels of leadership and leader self-sacrifice, but a significant interaction effect occurred in the transactional leadership condition. What is likely to have happened is that, in the transactional leadership condition, followers perceived high levels of leader self-sacrifice as an excessive level of involvement, compared to other leader behaviors. This could indicate the presence of strong self-interest in tasks and activities, which sits uncomfortably alongside the administering by transactional leaders of positive reinforcement and rewards, and their utilization of negative reinforcement such as punishment, reprimands, and negative feedback when mistakes, violations, or failures occur.

There are several limitations in this study; firstly the homogeneity of the sample, which consisted of call center employees. It is possible that work groups characterized by a lower level of control over their tasks or by higher levels of independence would have given different responses, especially in regard to team identification. 
Second, the self-report measures that we used were unaccompanied by choice behavior assessment. Our focus was on individual perception, but future investigation of both individual perception and leaders' behaviors in real work contexts should produce a better understanding of the issues.

We argue that our findings are an important addition to the literature, because of the impact leaders have on subordinates' attitudes and behaviors. All these aspects of leadership need to be considered by future researchers so that groups may have the benefit of a carefully designed workplace in which the right leader is in the right place. This is based on the principle that some leaders' styles are more suitable than others for achieving specific group objectives, given that they follow a logic of affordances determined by the type of interaction used in the work context.

\section{References}

Aiken, L. S., \& West, S. G. (1991). Multiple regression: Testing and interpreting interactions. Newbury Park, CA: Sage.

Bass, B. M. (1985). Leadership and performance beyond expectations. New York: Free Press.

Bass, B. M., \& Avolio, B. (1995). Multifactor Leadership Questionnaire leader form (5X-short). Redwood City, CA: Mind Garden.

Choi, Y., \& Mai-Dalton, R. R. (1998). On the leadership function of self-sacrifice. The Leadership Quarterly, 9, 475-501. http://doi.org/c68cbj

Choi, Y., \& Mai-Dalton, R. R. (1999). The model of followers' responses to self-sacrificial leadership: An empirical test. Leadership Quarterly, 10, 397-421. http://doi.org/d2vcdc

Conger, J. A., \& Kanungo, R. N. (1987). Toward a behavioral theory of charismatic leadership in organizational settings. Academy of Management Review, 12, 637-647.

Conger, J. A., \& Kanungo, R. N. (1998). Charismatic leadership in organizations. Thousand Oaks, CA: Sage.

De Cremer, D., \& van Knippenberg, D. (2004). Leader self-sacrifice and leadership effectiveness: The moderating role of leader self-confidence. Organizational Behavior and Human Decision Processes, 95, 140-155. http://doi.org/bv2hzc

Gundlach, M., Zivnuska, S., \& Stoner, J. (2006). Understanding the relationship between individualism-collectivism and team performance through an integration of social identity theory and the social relations model. Human Relations, 59, 1603-1632. http://doi.org/c2nv8f

Hoogervorst, N., De Cremer, D., van Dijke, M., \& Mayer, D. M. (2012). When do leaders sacrifice? The effects of sense of power and belongingness on leader self-sacrifice. The Leadership Quarterly, 23, 883-896. http://doi.org/mmr

Mael, F., \& Ashforth, B. (1992). Alumni and their alma mater: A partial test of the reformulated model of organizational identification. Journal of Organizational Behavior, 13, 103-123. http:// doi.org/dxg53x

Purvanova, R. K., \& Bono, J. E. (2009). Transformational leadership in context: Face-to-face and virtual teams. The Leadership Quarterly, 20, 343-357. http://doi.org/dnmp8p

Riketta, M. (2005). Organizational identification: A meta-analysis. Journal of Vocational Behavior, 66, 358-384. http://doi.org/btzjqx

Ruggieri, S. (2009). Leadership in virtual teams: A comparison of transformational and transactional leaders. Social Behavior and Personality: An international journal, 37, 1017-1021. http://doi. org/b5wt3d 
Scaffidi Abbate, C., \& Ruggieri, S. (2008). A beggar, self-awareness and willingness to help. Current Psychology Letters: Behaviour, Brain and Cognition, 24, 98-107.

Scaffidi Abbate, C., \& Ruggieri, S. (2011). The fairness principle, reward, and altruistic behavior. Journal of Applied Social Psychology, 41, 1110-1120. http://doi.org/dwx6tg

Shamir, B., House, R. J., \& Arthur, M. B. (1993). The motivational effects of charismatic leadership: A self-concept based theory. Organization Science, 4, 577-594. http://doi.org/b9wgr3

van Dick, R., Hirst, G., Grojean, M. W., \& Wieseke, J. (2007). Relationships between leader and follower organizational identification and implications for follower attitudes and behaviour. Journal of Occupational and Organizational Psychology, 80, 133-150. http://doi.org/cdzg8h

van Knippenberg, D., \& van Schie, E. C. M. (2000). Foci and correlates of organizational identification. Journal of Occupational and Organizational Psychology, 73, 137-147. http://doi. org/dv5dbq 